\title{
THE INTERDISCIPLINARITY OF FORENSIC SCIENCES IN THE EDUCATIONAL SPHERE: AN ANALYSIS OF THIS CONTEXT IN SECONDARY SCHOOL
}

\author{
Shirlene Carmo ${ }^{1}$, Luís Souto ${ }^{2}, \&$ Carlos Silva ${ }^{3}$ \\ ${ }^{1}$ Department of Exact and Natural Sciences, Federal Rural University of the Semi-Arid Region (Brazil) \\ ${ }^{2}$ Department of Biology, University of Aveiro (Portugal) \\ ${ }^{3}$ Department of Education and Psychology, University of Aveiro (Portugal)
}

\begin{abstract}
Many students when entering higher education, mainly in courses of exact or natural sciences and engineering, have difficulties in following the initial contents taught, due in part to the lack of knowledge arising from unique traditional methodology applied during their training. Some graduations even promote leveling courses in order to try reducing the deficits brought from previous education. Subjects such as Differential and Integral Calculus that are on the curricular basis of these courses, show high failure rates, strongly linked to gaps in previously acquired knowledge in mathematics. These factors directly contribute to the increase in retention rates and school dropout. So, there is a relentless search for improvement in the teaching-learning of these sciences, in order to motivate students, still in required education to knowledge building. It is commonly observed that young people are very attracted to the scientific disclosures broadcast by the media, as can be seen in the investigative series, which use forensic expertise for solving cases of a judiciary nature. In this sense, this work aimed to summarize studies that have been developed and implemented about the use of forensic sciences in the promotion of teaching-learning in secondary schools. The methodology was based on exploratory qualitative research. The results are based on experiences that occurred in the school context in USA, Brazil and Portugal, where it appears that students are more involved in the development of educational activities when integrated in a forensic like context, benefiting from collaborative work when trying to arrive to a common goal, similar to the assignment of a true forensic scientist. This allows them to recognize the importance of these contents, facilitates the presentation before the classroom, while improving the interaction with the social environment in which they are inserted. Teacher's feedback confirms the beneficial implementation of these activities in the educational context and considers it with potential to attract attention and awaken the interest of these students in the sciences, thus improving the comprehension of theoretical concepts of the contents integrated in the school curriculum. The interdisciplinarity implemented on the production and socialization of knowledge is necessary and decisive to promote effective teaching and learning. The Forensic Sciences contemplate this interdisciplinarity and contribute that students feel more involved and motivated in learning, reducing retention rates and school dropout and increasing the search for science and technological careers.
\end{abstract}

Keywords: Teaching-learning, scientific methodology, criminal investigation, school dropout, CSI effect.

\section{Introduction}

According to D'Ambrosio (1996), education should strategically develop in individuals, promoting stimuli that contribute to individual and collective relationships to be developed in a given culture. Science education is seen as essential since the first years of schooling, because it prepares students for a more adapted social experience and a qualified professional life. Silva, Vieira and Ferreira (2017) address points that directly affect the teaching-learning process, including the school structure, the absence of science laboratories and inadequate teacher training.

In Brazil is high number students that enter Universities, especially in courses of exact and natural sciences, which presenting difficulties due to failure in the learning process throughout their compulsory education, especially when they come from public schools, where there is a strong absence teacher with training in the area and little didactic support structure for development of teaching. 
Until 2018, according to ODCE (2020), the proportion of young adults without a complete secondary school education in Brazil was still large compared to other developed countries. On average, in OECD countries, $47 \%$ of young people (aged 18 to 24 ) have left the educational system, which is closely related with the transition from high school to college. Also according to ODCE (2020), Brazil, Colombia, Israel and New Zealand, more than $65 \%$ of these young adults aren't longer studying. Brazil has two concerns: raising the quality of education, as developed countries also seek, and raising school attendance.

Especially nowadays, the dissemination of scientific knowledge transcends the need and becomes a daily challenge in educators' lives. The educator needs to reinvent himself, reform himself, and mainly, develop works and research based on subjects or problems in his daily life, this will make all this mobilization for teaching-learning become something significant for such.

To understand the disciplines of the exact and natural sciences, whose are integrated in the natural sciences, mathematics and their technologies, according to the areas of knowledge in secondary school as per article 35 LDB (Brazil, 2017a), isn't an easy task for many students, because different contents are difficult to assimilate, especially when taught by traditional method, considered by many students as tedious and preachy. This demotivation has increasingly contributed to academic retention and dropout rates.

Articles arranged by (Brasil, 1996) and (Brasil CNE, 1998) aim to be a learning guide to a greater contextualization, an effective interdisciplinarity and a broader human formation, not only technical, but already advise a greater relationship between theory and practice in their own learning process.

In the incessant search to improve education, Forensic Sciences (FS) emerge as a scientific methodology, where its content naturally lends itself to learning based on constructivist research, because students are asking questions constantly, evaluating evidence and use critical thinking to provide explanations for the issues under analysis.

FS is the science application that answers questions of legal importance, thus it plays a crucial role in the resolution of criminal and civil investigations (Hemanth, Tharmavaram and Pandey, 2020). In addition, its broad, diversified and integrating context allows it to interconnect several areas of knowledge and science, such as Mathematics, Physics and Chemistry, Medicine, Engineering, which makes it an interdisciplinary science.

In recent years, the FS have been gaining space and attention for their great contribution to resolution of judicial cases. Through this high interest on the part of the general population, the so-called "CSI effect" appears, which has given young people, in particular, a great motivation for the area.

Given the above, this theme becomes extremely relevant when it comes to be worked in the classroom, as the methodology is student-centered, allowing that student to develop critical thinking and reasoning, in addition to creativity and independence in the classroom, seeking to integrate various disciplines, thus expanding the range of observations and everyday social life phenomena. The use of this tool promotes scientific literacy, the search for scientific technological careers and is a strategy to decrease dropout and retention rates.

In this sense, this work aimed to synthesize the studies that have been developed and implemented in FS as a pedagogical practice in the promotion of teaching-learning in secondary schools. Due to its interdisciplinary nature, this scientific methodology allows to contextualize, through motivating and challenging facts, various disciplines within the school education.

\section{Methodology}

The present study was based on a qualitative approach located within the exploratory research paradigm by a systematic literature review. Qualitative design was appropriate for this study, because it provides consistent information about the context and provides an understanding of the factors being observed (McLeod, 2017). The study explored pedagogical practices around Forensic Sciences adopted in the educational context of secondary education in the USA, Brazil and Portugal. The analyzes were identified from research with qualitative and quantitative approaches, where it was possible to attest to improvements in interest and performance in the exact and natural sciences subjects, which are largely responsible for the retention rates and school dropout in secondary education.

\section{Findings and discussion}

Secondary school has been a focus on many educational researches around the world and, in relation to Brazilian educational system, it is the level of education that provokes the biggest debates, whether due the persistent problems of retention and school dropout; for the lack of curriculum attractiveness; for the quality of the education offered or even, for discussion about their identity (Souza, 2016). Search for methodological alternatives that promote students' interest and motivation, especially in teaching in the exact and natural sciences, becomes increasingly indispensable. 
At an international level, Saccaro et al. (2019) found that dropout in Higher Education is the result of several reasons, among which is the quality education in compulsory schooling. Differential and Integral Calculus disciplines, for example, inserted in courses of exact and natural sciences, and Engineering, they present high retention rates, resulting many times, from the lack of background knowledge in physics and mathematics acquired during their previous training. (Bigotte de Almeida; Queiruga-Dios; Cáceres, 2021).

Students' Science, Technology, Engineering and Mathematics (STEM) have more likely to drop out of course that students in different areas of knowledge, they instead providing motivation for the technical-scientific area, end up being a barrier one for professional access, contributing for reduction more and more to choose a STEM career (Costa, 2020).

The search for scientific methodologies that provide motivation and interest for exact and natural sciences, make the Forensic Sciences with high didactic potential for students' learning and intellectual development in their knowledge construction, which is essential for social and professional experience. These allow advances in the concepts and processes explained in the classroom. Thus, several studies have been developed in order to validate the insertion of this methodology in the school context as a strategy to improve the teaching-learning process.

Raza (2012) applied a mixed approach of quantitative and qualitative nature to secondary school students, where research-based instruction in the forensic context examined its influence on the use of higher-order thinking skills (HOTS) and development characteristics of scientific literacy. The quantitative data revealed an increasing level of higher-order thinking across the sequence of topics and an improved use of these skills as the forensic science curriculum progressed. The qualitative analysis indicated as main results, benefits of collaborative work in the problem-solving process, HOTS in knowledge formation and connections between classroom learning and real-world applications. The results of this study indicated that forensic science can be used as a pedagogical practice to promote scientific literacy.

The research developed by Rocha, Garrido and Garrido (2014), experiments containing interdisciplinary themes involving forensic sciences were tested in natural science classes. The proposed experiments proved to be easily adapted to the reality of these schools to promote the learning of natural sciences disciplines, especially chemistry and biology. In an analysis based on interviews applied to secondary school students, it is observed that there is an absence of practical teaching in the natural sciences subjects, and about $94 \%$ of these students have great interest in improving learning through practical classes, especially when these classes are contextualized related to criminal expertise themes. $90 \%$ of the interviewed students had already watched investigative films and series, this finding opens an important opportunity to bring scientific knowledge in natural sciences for all students, since they indicated that these contents didn't arouse their interest. They also demonstrated that the use of topics related to Forensic Sciences inserted in the scientific bases teaching would provide more motivation and certainly result in great benefits to the teaching-learning process.

Souto et al. (2015) proposed the use of a Forensic Sciences Educational Kit, designed to be used by secondary school students under the teacher's supervision. From activities that explore forensics cases, it was possible to relate these activities to curricular subjects, such as Biology, Chemistry, Physics and Mathematics. The teachers' feedback confirms the beneficial results through the implementation of these activities in the educational context and considers it with great potential to attract attention and arouse the interest of these students for sciences, thus improving students' learning by developing their understanding of the theoretical concepts in the school curriculum. They also believe that the Educational Forensic Kit can be additional to other educational resources, contributing to minimize the lack of interest and school students dropout at critical ages, as well as contributing to the motivation in educational agents.

Munayera (2018) investigated the use of a suspense paradidactic book about real facts in Forensic Sciences. The technique used in this scientific methodology implementation allowed the use of chemical science topics taught in the secondary school to promote students' productive disciplinary engagement, once they were motivated to solve the cases present in the book, through an investigative analysis. The results allowed us to realize, from a qualitative analysis, the interest, motivation, performance and students' engagement in classes during the performance of this practice. The students were able to understand-experience a new way of scientific concepts and ideas worked in the school context.

Santos and Amaral (2020) applied in their study an activities series related to Forensic Chemistry to promote a meaningful chemistry learning. The action research approach was a qualitative type applied to secondary school students. The activities involved crime-solving. The results showed Forensic Chemistry as a contextualizing theme in the chemistry teaching, improved greater involvement, interest and motivation for students. Analyzing the entire progress of the research, from a previous analysis, during and after the development of the activities, it is possible to perceive the promotion of a potentially meaningful learning by using this method. 
In work developed by Lino, Sá e Silva (2020) they used a learning model including Forensic Sciences interactions aiming to establish new pedagogical motivational practices for 3rd year secondary students. The practice was based on the crime scene simulation made up of several pieces of evidence distributed throughout the scene. This enabled an effective participation of students in the proposed activities around the criminal expert routine. The data indicate that the natural sciences still face a low acceptance among students, however the forensic practices simulations inserted in didactics in the classroom, contributed to scientific stimulation of students by the interconnection between theory and practice, promoting curiosity and helping them to keep them motivated within the teaching-learning process.

The inclusion of forensic scientific topics in school didactics improves students' participation in active learning and contributes to use of critical thinking skills, to scientific literacy and to interpersonal relationships through collaborative work. Interdisciplinarity contextualization of forensic themes contents, in addition to benefiting learning stimulate interest for technological areas in which these sciences are inserted.

\section{Conclusions}

Subjects such as Physics, Mathematics, Chemistry and Biology, aren't always favored by students, many find boring subjects, they think they just won't use those concepts in life. The insertion of Forensic Sciences as a scientific methodology of an interdisciplinary complementary nature to other educational resources, allows the observation of real-life phenomenon present in everyday and contributes to the autonomy of secondary school students, allowing them to feel more involved and motivated in learning, thus providing an improvement in teaching-learning in the exacts and natural sciences, consequently, reducing retention rates and school dropout in curricular components. An interdisciplinary approach presented in Forensic Sciences, provides to teaching these sciences, a methodology centered on the student, allowing him to develop a greater engagement in learning, seeking to integrate various disciplines, thus expanding the range of observations and social phenomenon of everyday life. The reflection of these proposed actions leads to benefits in a horizon that goes beyond the barrier to secondary school, can be observed in a more qualified basic education in the student who reaches higher education and will be decisive for his success during the course.

\section{References}

Bigotte de Almeida, M.E.; Queiruga-Dios, A.; Cáceres, M.J. (2021). Differential and Integral Calculus in First-Year Engineering Students: A Diagnosis to Understand the Failure. Mathematics, 9(1), 61. Retrieved Jan 18, 2021, from: https://doi.org/10.3390/math9010061

Brasil. Lei $\mathrm{n}^{\circ} 13.415$, de 16 de Fev de 2017. Altera as Leis $n^{\circ}$ 9.394, de 20 de dezembro de 1996, que estabelecem as diretrizes e bases da educação nacional. Diário Oficial da União, Brasília, DF, 17 fev. 2017. Retrieved Jan 15, 2021, from http://www.planalto.gov.br/ccivil_03/_Ato20152018/2017/Lei/L13415.htm\#art3

Brasil. Lei n ${ }^{\circ}$ 9.394, de 20 de dezembro de 1996. Estabelece as diretrizes e bases da educação nacional. Diário Oficial da União, Brasília, DF, 23 dez. 1996. Retrieved Jan 10, 2021, from http://www.planalto.gov.br/ccivil_03/leis/19394.htm

Brasil. Ministério da Educação. Conselh̆o Nacional de Educação. Parecer CNE/CP n ${ }^{\circ} 11 / 2009$. Proposta de experiência curricular inovadora do Ensino Médio. Brasília, DF, 2009. Retrieved Jan 10, 2021, from http://portal.mec.gov.br/index.php?option=com_docman\&view=download\&alias=1685pcp011-09-pdf\&category_slug=documentos-pdf\&Itemid $=\overline{3} 0192$

Costa, H. A. (2020). Determinant factors of evasion in brazilian's private higher Education Institutes. Work Project (Master's Degree in Management). Nova School of Business and Economics and Insper, Carcavelos - PT. Retrieved Fev 25, 2021, from: http://hdl.handle.net/10362/108609

D’Ambrosio, U. (1996). Educação Matemática: Da Teoria à Prática. (Coleção Perspectivas em Educação Matemática). Campinas: Papirus.

Dias Filho, C. R.; Antedomenico, E. (2010). A perícia criminal e a interdisciplinaridade. Química Nova na Escola, v. 32, n. 02, p.67-72. Retrieved Fev 22, 2021, from: http://qnesc.sbq.org.br/online/qnesc32_2/02-QS-6309.pdf

Hemanth, K.; Tharmavaram, M.; Pandey, G. (2020). History of Forensic Science. Technology in Forensic Science: Sampling, Analysis, Data and Regulations, p. 1-16, Wiley-VCH. 
Lino, M.; Sá, M.; Silva, C. (2020). Ciência Forense: Uma abordagem da identificação humana no ensino de ciências. International Journal Education and Teaching (PDVL), 3(2), 31 - 49. Retrieved Mar 03, 2021, from: https://doi.org/10.31692/2595-2498.v3i2.133

Munayera, T. K. A. (2018). Utilização de contos de suspense e atividades investigativas no processo de ensino e aprendizagem de química na educação básica: uma proposta de um paradidático sobre ciência forense. Dissertação (Mestrado Profissional em Ensino de Ciências). Universidade Federal de Ouro Preto, Ouro Preto - MG. Retrieved Fev 17, 2021, from: http://www.repositorio.ufop.br/handle/123456789/9914.

OECD (2020), Education at a Glance 2020: OECD Indicators, OECD Publishing, Paris. Retrieved Jan 30, 2021, from https://doi.org/10.1787/69096873-en.

Raza, G. B. (2012). Using Forensic Science as a Context to Enhance Scientific Literacy. Ph.D (Doctor of Philosophy). Columbia University. New York, EUA. Retrieved Fev 15, 2021, from https://academiccommons.columbia.edu/doi/10.7916/D8ZW1T8K/

Rocha, G. X., Garrido, F., \& Garrido, R. G. (2014). Forensic approach to improving science teaching in high school. Procedia-Social and Behavioral Sciences, v. 116, p. 4293-4296. Retrieved Fev 06, 2021, from https://www.sciencedirect.com/science/article/pii/S1877042814009513

Santos, F. R. dos; Amaral, C. L. C. (2020). Forensic chemistry as a contextualizing theme in the teaching of chemistry. Research, Society and Development, vol. 9, n.3, p. e198932772. Retrieved Fev 22, 2021, from http://dx.doi.org/10.33448/rsd-v9i3.2772.

Silva, A. F. da; Ferreira, J. H.; Vieira, C. A. (2017). O ensino de ciências no ensino fundamental e médio: reflexões e perspectivas sobre a educação transformadora. Revista Exitus, v.7, n.2, p. 283-304. Retrieved Fev 27, 2021, from: 10.24065/2237-9460.2017v7n2ID314.

Souto, L., Tavares, F., Moreira, H., Fidalgo, R., Pinho, R., Mendes, A., \& Pombo, L. (2016). Forensic Toolbox: Proposta de kit forense educativo. Indagatio Didactica, 8(1), 1709-1723. Retrieved Fev 14, 2021, from https://proa.ua.pt/index.php/id/article/view/11897/7873.

Souza, T. A. (2016). Ciência forense como lugar interdisciplinar no ensino médio: uma experiência docente. Dissertação (Mestrado profissional em Ensino de Ciências). Universidade Federal de Itajuba, Itajuba - MG, Retrieved Mar 02, 2021, from: https://repositorio.unifei.edu.br/jspui/handle/123456789/469 